ISSN : 1978-4333, Vol. 03, No. 02

\title{
Independensi Lembaga Swadaya Masyarakat (LSM) di Tengah Kepentingan Donor
}

\author{
Husain Assa' di, Arya Hadi Dharmawan, dan Soeryo Adiwibowo
}

\begin{abstract}
The top-down development approach has failed to bring Indonesia in meeting prosperity. Alternatively, a critical approach as offered by Non Governmental Organization (NGO) becomes much more attractive to be adopted. However such approach encounters problematics since each NGO carries its own interest, ideology, and its dependency on donor agencies, normally diametrically collide with another NGO's ideology, its interest as well as donor-supported interest. This study is to answer the question how deep have donors infleunced to the ideology, interest, and financial independency of local NGOs. The study use qualitative method as approach. The financial arrangement network, action, interest, motives and NGOs' ideologies are the main focus of this study. Two NGOs are observed, namely Lembaga Kajian untuk Transformasi Sosial (LKTS) and Lembaga Pertanian Sehat (LPS). This study revealed that LKTS and LPS were quite dependent in the financial aspect. LKTS was also dependent in formulating action, while LPS was independent. Some factors affecting the independence of NGOs are: (1) degree of militancy of NGOs' ideology, (2) financial strength, (3) NGOs' level of achievements. In the development perspective, NGOs are not necessarily reflecting type of social movement organization which are always strongly based on bottom-up ideology.
\end{abstract}

Keywords: social movement organization, NGO, development approach, local participation, empowerment

\section{PENDAHULUAN}

\section{Latar Belakang}

Munculnya gerakan sosial masyarakat sipil yang berlangsung di negara berkembang dapat dipandang sebagai alternatif pendekatan perubahan sosial yang dominan (mainstream approach) atau lebih dikenal dengan perubahan sosial yang direkayasa oleh negara melalui apa yang disebut dengan pembangunan (Fakih, 2000). Modernisasi sebagai salah satu pendekatan pembangunan seringkali menempuh cara/mekanisme pertumbuhan sebagai strategi utamanya. Hal ini antara lain ditunjukkkan oleh diadopsinya Teori Rostow sebagai kerangka pembangunan. Teori ini menjelaskan adanya lima tahapan ekonomi dalam perkembangan suatu negara (Rostow, 1964). Dalam perjalanannya, teori ini telah menuai beragam kritik, diantaranya disampaikan oleh Frank (1973) dengan teori ketergantungan. Menurut 
Frank (1973), modernisasi ternyata membawa kemacetan ekonomi, krisis ekologi, serta kesengsaraan rakyat di dunia ketiga ketimbang kemajuan dan kemakmuran.

Menurut Fakih (2000) praktek-praktek pembangunan selama ini selalu menekankan pengalihan modal, perencanaan formal, spesialisasi, dan pengendalian oleh pemerintah pusat. Teori-teori pembangunan konvensional yang dijadikan dasar sangat menekankan pentingnya meletakkan tanggung-jawab pengendalian dan pengalokasian sumber-sumber pembangunan pada pemerintahan terpusat, karena dengan demikian dianggap akan dapat dihasilkan pengambilan keputusan yang optimal tentang investasi. Billah (1988) mengatakan bahwa pendekatan sistem komando atas pengelolaan sumber-sumber ini lebih sering menghasilkan pemantapan sistem patronase dan membangun proyek-proyek ekonomi yang lembek, mengabaikan kemandirian, meningkatkan ketergantungan pada sumbersumber luar, dan menggusur prakarsa lokal. Selain itu, pendekatan semacam ini cenderung mendorong ke arah otoritarianisme, dan pemusatan kekayaan dan kekuasaan politik. Sebagai tanggapan terhadap kecenderungan itu, kemudian muncullah suatu tuntutan agar pembangunan lebih berkiblat pada rakyat yang menekankan pentingnya penguatan kapasitas kelembagaan dan sosial yang mendukung pengembangan pengendalian, pertanggung-gugatan (accountability), prakarsa, dan kemandirian lokal. Pengalihan modal dilihat sebagai bukan masalah yang paling utama, dan sebaliknya prioritas diutamakan pada proses demokratisasi. Rakyat didorong untuk memobilisasikan dan mengelola sumber-sumber mereka sendiri. Dengan pendekatan yang terdesentralisasikan dan penekanan pada kemampuan mengorganisasikan-diri untuk mengelola sumber-sumber pembangunan seperti itu, pada umumnya akan dihasilkan suatu pengelolaan sumber-sumber yang lebih effisien dan produktif, peningkatan prakarsa dan pertanggung-gugatan lokal, dan penguatan disiplin ekonomi. Pendekatan seperti yang disebut terakhir ini seringkali digunakan oleh LSM yang pada prakteknya cenderung memiliki minat yang kuat dalam demokratisasi (Korten, 1987).

Kegagalan penerapan modernisasi di Indonesia sudah selayaknya menjadi pelajaran berharga dalam menata kehidupan rakyat kedepannya. Pendekatan yang mengagungkan pertumbuhan ekonomi tanpa melihat secara lebih holistik hubungan manusia dengan alamnya telah nyata membawa kerusakan tidak saja pada alam tetapi juga telah dirasakan membawa petaka bagi manusia. Revolusi Hijau adalah contoh jalan yang baru kemudian diyakini telah merusak lingkungan dan tata sosial. Lenyapnya keanekaragaman hayati, resistensi hama, tanah jenuh karena overdosis pupuk dan hilangnya pola bertani yang ramah lingkungan adalah bukti bahwa kebijakan yang selama ini diambil salah.

Selain itu, secara sosiologi pendekatan yang selama ini dilakukan dalam menata kehidupan bernegara lebih bersifat top down (Sheperd, 1998). Masyarakat cenderung dibiarkan pasif, dimanjakan dan dipaksa untuk melaksanakan program yang berasal dari atas tanpa adanya usaha memandirikan mereka. Revolusi Hijau dengan swasembada beras sebagai icon keberhasilan pada era 80-an menjadi bukti bahwa pendekatan top down bukan strategi yang tepat bagi pembangunan di Indonesia. Untuk itulah diperlukan strategi pembangunan yang tepat.

Shepherd (1998) mengkritik pendekatan pembangunan yang dilakukan oleh negara yang cenderung top down, perlu adanya kelompok sosial yang mampu 
menggerakkan komunitas sehingga berdaya dimana publik mengenalnya sebagai organisasi gerakan sosial. Gerakan masyarakat sipil yang memperkuat entitas ini berhadapan dengan pasar dan negara. Gerakan sosial yang terorganisir dengan baik, dimana rencana aksi kolektif mewujud dalam perancangan kegiatan nyata pada masyarakat akar rumput, diantaranya ditunjukkan oleh gerakan sosial akar rumput, yang dikenal luas sebagai Lembaga Swadaya Masyarakat (LSM).

Perkembangan Lembaga Swadaya Masyarakat (LSM) di Indonesia pada tahun 1970 sangatlah mengesankan bila ditinjau dari jumlah, keragaman, dan letak geografinya (Fakih, 2000). Sebagai kekuatan yang bekerja di akar rumput, LSM mempunyai fungsi strategis sebagai pelopor yang melayani perubahan sosial dalam penguatan ranah sipil. LSM dengan isu lingkungan hidup mengalami perkembangan yang sangat cepat. World Wide Foundation (WWF) misalnya, LSM yang didirikan di Switzerland pada tahun 1961 dengan kantor kecil dan staf hanya 25 orang pada tahun 70an, pada tahun 1980 sudah tumbuh menjadi 300 staf dan pada tahun 2004 LSM ini sudah mempekerjakan lebih dari 4000 staf yang tersebar di 90 negara (Chapin, 2004). Begitupula jika menyimak perkembangan TNC (The Nature Conservation), sebuah LSM yang fokus pada isu konservasi. LSM ini didirikan pada tahun 1951 dan pada tahun 1970 sudah berkembang ke 50 negara (Chapin, 2004). Tidak sekedar jumlah, besarnya perputaran uang pada lembaga ini juga tidak kalah kecil, WWF melaporkan pada tahun 2003 pemasukan lembaga ini mencapai \$380 juta (sekitar 3,4 trilyun rupiah). TNC lebih besar lagi, pada tahun 2000 perputaran uang mencapai $\$ 786,8$ juta (sekitar 7,2 trilyun rupiah) sehingga dijuluki world's richest conservation organization (Chapin, 2004).

Di Indonesia, pertumbuhan jumlah LSM, tidak dapat dipisahkan dari keseluruhan diskursus pembangunan. Sehingga pembahasan tentang LSM juga tidak dapat dipisahkan dengan wacana yang terkait dengan struktur negara (Eldrigde, 1989). Keberadaan LSM sebagai bagian dari ranah sipil (Civil Sphere) akan berkaitan pengaruh dengan ranah negara (State Sphere) dan ranah pasar (Market Sphere) seperti yang dijelaskan oleh Bebbington dalam Dharmawan (2002).

Hasil studi tentang LSM sudah cukup banyak, kaitannya dengan struktur negara dan cakupan wilayah kerja LSM. Nordholt (1987) membagi LSM menjadi tiga tipe, yaitu: LSM Besar (Big NGO), LSM menengah (Regional NGO), dan LSM Lokal (Local NGO). Menurut Nordholt (1987), Semakin besar cakupan wilayah LSM, maka akses ke lembaga-lembaga besar (termasuk didalamnya struktur pemerintah dan pasar) akan semakin mudah. Hal ini akan berimplikasi pada kekuatan nilai tawar dan akses dana. Sementara, LSM kecil pada kondisi ini sebaliknya, LSM kecil memiliki posisi tawar yang rendah dan akses pendanaan yang terbatas.

Pertumbuhan LSM yang demikian cepat dengan keragaman fokus isu yang diangkat (Fakih, 2000. Nordholt, 1986. Eldridge, 1987) bila bandingkan dengan data angka kemiskinan BPS dari tahun 1996-2008 (BPS, 2008), peningkatan jumlah LSM tidak berpengaruh (lihat Gambar 1).

Pada Gambar 1. dapat diketahui bahwa peningkatan jumlah LSM tidak diikuti dengan hasil nyata turunnya angka kemiskinan. Padahal isu kemiskinan adalah isu yang paling banyak menjadi fokus kegiatan LSM di Indonesia (Korten, 1987). Angka kemiskinan pada tahun 1996 sampai dengan menunjukkan kondisi yang 
relatif tetap, sempat ada kenaikan pada tahun 1998 tetapi bisa dipahami karena pada tahun terebut terjadi krisis ekonomi di Indonesia, dan kemudian terjadi penurunan akibat meredanya krisis. Kondisi ini menarik untuk dicermati, di satu sisi LSM dengan fokus isu kemiskinan berkembang sangat pesat di Indonesia tetapi selama itu tidak terjadi penurunan angka kemiskinan. Sehingga muncul pertanyaan kritis mengenai hasil kinerja LSM sebagai agen pembangunan alternatif yang mengalami kesenjangan antara tujuan dan kenyataan yang ada. Salah satu pendekatan untuk memahami masalah ini adalah dengan merujuk hasil penelitian dari Ufford dan Giri (2002) mengenai praktik agen pembangunan alternatif yang tidak memiliki konsistensi dalam memperjuangkan visi dan idealismenya, melainkan hanya menjadi pelaksana kekuatan lain yang lebih besar.

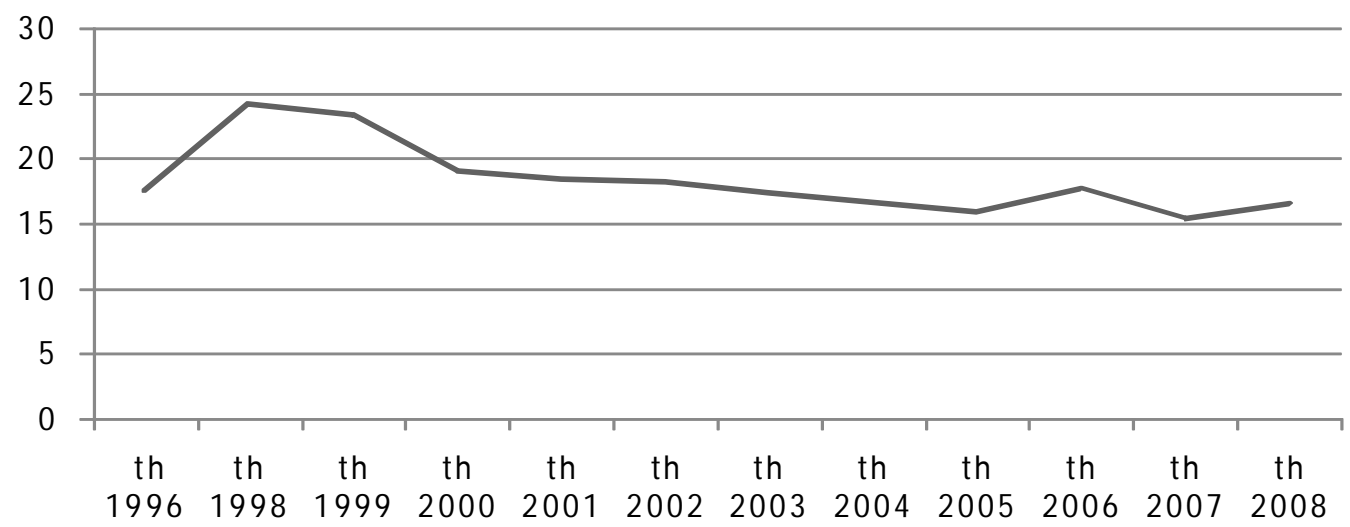

\begin{tabular}{|l|l|l|l|l|l|l|l|l|l|l|l|l|} 
Tahun & 1996 & 1998 & 1999 & 2000 & 2001 & 2002 & 2003 & 2004 & 2005 & 2006 & 2007 & 2008 \\
\hline
\end{tabular}

\begin{tabular}{|l|l|l|l|l|l|l|l|l|l|l|l|l|}
\hline Prosentase & 17,47 & 24,23 & 23,43 & 19,14 & 18,41 & 18,2 & 17,42 & 16,66 & 15,97 & 17,75 & 15,42 & 16,58 \\
\hline
\end{tabular}

Gambar 1. Grafik Prosentase Angka Kemiskinan di Indonesia

Tahun 1996-2008

Secara ideal LSM adalah organisasi yang muncul dari ranah sipil yang tentunya memperjuangkan hak-hak sipil sebagai agen alternatif pembangunan (Fakih, 2000. Budiman, 1988. Hannam, 1988.), tetapi pada kenyataannya agen pembangunan alternatif ini tidak bebas kepentingan (Ufford dan Giri, 2002). Munculnya istilah menjual isu lingkungan, isu kemiskinan, isu pemberdayaan, dengan mengatasnamakan LSM adalah bentuk respon publik terhadap diskursus ini. Dalam konteks ini LSM dicurigai marak membuat pengajuan dana dan kemudian aktivisnya didanai oleh donor dan LSM hanya sebagai kepanjangan tangan dari kepentingan donor. Pada titik inilah penulis melihat ada relevansi pembahasan mengenai LSM sebagai elemen agen pembangunan alternatif ditengah idealismenya memperjuangkan kepentingan sipil dan dinamikanya terhadap kepentingan donor.

\section{Perumusan Masalah}

Modernisasi dengan konsep pertumbuhan ekonomi sebagai strategi pembangunan, telah dijalankan oleh Bangsa Indonesia dalam membangun. Pembangunan pedesaanpun tidak lepas dari strategi ini. Shepherd (1998) menyebutnya sebagai paradigma lama pembangunan pedesaan (old paradigm of rural development). 
Dharmawan (2002) memberikan ilustrasi pendekatan pembangunan ini sebagai pendekatan yang sarat dengan pesan-pesan ekonomi, pertumbuhan, perubahan nilai budaya lokal, westernisasi, dan investasi modal. Yang pada akhirnya, secara nyata telah membawa akibat buruk pada tata kehidupan sosial dan rusaknya lingkungan.

Perkembangan LSM di Indonesia yang sangat cepat tidak diiringi dengan hasil yang nyata dalam proses pengentasan kemiskinan. Secara ideal LSM adalah organisasi dengan kesadaran dan semangat kesukarelaan yang muncul dari ranah sipil yang memperjuangkan hak-hak sipil sebagai agen alternatif pembangunan (Fakih, 2000. Budiman, 1988. Hannam, 1988.), tetapi pada kenyataannya agen pembangunan alternatif ini tidak bebas kepentingan (Ufford dan Giri, 2002). Petras dan Veltemeyer (2002) mengemukakan sebagai berikut:

\begin{abstract}
"Ornop-ornop di seluruh dunia telah menjadi alat terakhir untuk mobilitas naik bagi kelas-kelas terdidik yang ambisius. Para akademisi, jurnalis dan profesional telah semakin jauh dari kepedulian awal mereka pada gerakan kiri dan miskin dana. Dan mereka kini mengejar karier yang menguntungkan dengan mengelola Ornop yang akan memberikan keterampilan organisatoris dan retorika serta kosa kata populis tertentu. Sekarang ini ribuan direktur Ornop setiap hari naik kendaraan roda empat seharga US \$ 40.000 sebagai sarana transportasi dari rumah atau apartemen modern mereka di pinggiran kota ke kantor-kantor dan kompleks bangunan yang sangat lengkap. Sementara mereka meninggalkan anak-anak dan pekerjaan rumah tangga di tangan pembanru dan juga kebun-kebun mereka untuk dirawat oleh para tukang kebun. Mereka lebih akrab dan menghabiskan waktu di tempat-tempat konferensi internasional tentang kemiskinan yang sering mereka ikuti (Washington, Bangkok, Tokyo, Brussels, Roma dan lainnya) dari pada di kampungkampung berlumpur di negara mereka sendiri. Mereka lebih mahir menyusun proposal baru untuk mendapatkan uang demi para 'profesional' yang layak ditolong dari pada mengambil resiko terpukul kepalanya oleh polisi yang menyerang demonstrasi guru sekolah di desa yang gajinya tidak dibayar penuh. Para pemimpin Ornop adalah kelas baru yang tidak mendapatkan harta kekayaan dari kepemilikan atau sumber-sumber pemerintah, tetapi dari dana imperial dan kemampuanyya sendiri untuk mengontrol kelompok-kelompok rakyat yang signifikan"
\end{abstract}

Pernyataan diatas menyiratkan fakta dilapangan yang jauh dari idealisme LSM sebagai bagian dari masyarakat sipil yang berjuang untuk kesejahteraan masyarakat. LSM menjadi semacam perusahaan profit yang mengambil keuntungan sebesarbesarnya di tengah penderitaan rakyat sipil yang diperjuangkann. Lebih lanjut Petras dan Veltmeyer (2002) mengatakan:

"Para pemimpin Ornop bisa dipandang sebagai semacam kelompok neokomprador yang tidak memproduksi komoditas apapun yang bermanfaat, tetapi berperan memproduksi jasa untuk negara-negara donor dan menjual kemiskinan domestik untuk kekayaan pribadi”

Petras dan Veltemeyer (2002) memberikan pandangan bahwa LSM melakukan komodifikasi kemiskinan dan isu pembangunan, tanpa melihat lembaga donornya karena semua terjebak pada kondisi ini. Kutipan diatas juga menyiratkan kinerja 
LSM yang hanya berorientasi keuntungan pribadi atau kelompok LSM dibanding memperjuangkan hak-hak sipil.

Munculnya istilah menjual isu lingkungan, isu kemiskinan, isu pemberdayaan, dengan mengatasnamakan LSM adalah bentuk respon publik terhadap diskursus ini. Dalam konteks ini LSM dicurigai marak membuat pengajuan dana dan kemudian aktivisnya didanai oleh donor dan LSM hanya sebagai kepanjangan tangan dari kepentingan donor.

Walhi sebagai sebuah LSM lingkungan yang berdiri 15 Oktober 1980 adalah organisasi yang dari awal memposisikan diri mengambil jarak dengan pemerintah. Walhi lebih banyak mendapatkan dana dari donor internasional dari United States Agency for International Development (USAID), Australian Agency for International Development (AusAID), Novib, OXFAM, Asia Foundation , EZE. Belgium's National Center for Development Cooperation (NCOS), Department for International Development Agency (CIDA) dan lain-lain (Walhi, 2001). Hal ini dilakukan untuk menjamin independensinya dengan pemerintah selama orde baru, Walhi menyadari bahwa dana-dana dari pemerintah tidak akan lepas dari kepentingan, sehingga donor asing menjadi pilihan. Dengan posisi ini Walhi ingin mengambil posisi kritis dan independen terhadap pemerintah.

Pada akhir tahun 2000, Walhi membuat perencanaan jangka panjang yang bertolak belakang dari kebijakan awal. Bentuk perencanaannya adalah Walhi akan mulai mengalihkan sumber pendanaan dari donor asing (yang saat itu mencapai 90 persen) menuju dana lokal dari masyarakat lewat kegiatan-kegiatan partisipatif. Perubahan kebijakan ini didasarkan pada pengalaman selama bemitra dengan donor asing dan tarik menarik kepentingan LSM dan donor. (Culla, 2006). Kasus Walhi memberikan gambaran bahwa LSM adalah agen pembangunan alternatif yang dinamis dengan tarik-ulur kepentingan baik dari negara, swasta maupun sipil. Perjalanan Walhi, Penjelasan Petras dan Veltmeyer (2002) tentang LSM, mengetengahkan hangatnya pembahasan mengenai isyu subordinasi kekuasaan LSM dibawah donor dan subordinasi kepentingan, isyu infiltrasi kekuasaan asing, dan komodifikasi gerakan.

Pada titik inilah tampak adanya relevansi pembahasan mengenai LSM sebagai elemen agen pembangunan alternatif ditengah idealismenya memperjuangkan kepentingan sipil dan dinamikanya terhadap kepentingan donor. Pertanyaan yang muncul adalah apakah LSM memang akan memilih menjadi agen yang memberdayakan, atau sekedar menjadi kepanjangan tangan dari pemberi donor. Hal ini yang perlu diungkap sebagai bagian dari bentuk hubungan LSM dengan donor pada aspek-aspek yang dapat diteliti. Penelitian ini ingin melihat keragaan independensi LSM dalam konstelasi kepentingan donor, dengan menjawab rumusan pertanyaan sebagai berikut:

1. Apakah kepentingan donor memberi pengaruh pada independensi LSM dalam aspek finansial, aksi dan orientasi ideologi?

2. Apakah perubahan donor mempengaruhi independensi LSM? 


\section{Tujuan Penelitian}

1. Mengetahui apakah kepentingan donor memberi pengaruh pada independensi LSM dalam aspek finansial, aksi dan orientasi ideologi.

2. Mengetahui apakah perubahan donor mempengaruhi independensi LSM.

Kerangka Pemikiran

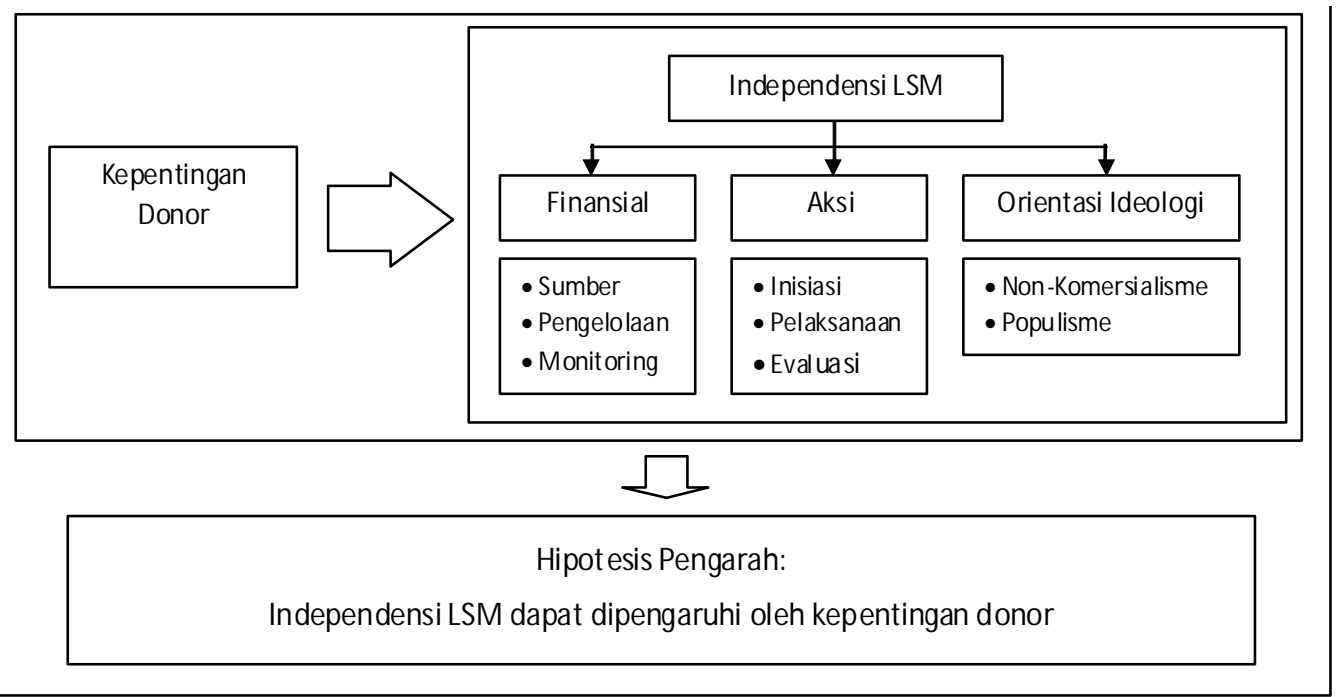

\section{METODE PENELITIAN}

\section{Lokasi dan Waktu Penelitian}

Penelitian ini dilakukan di Boyolali Jawa Tengah (LKTS) dan Cibadak Bogor Jawa Barat (LPS) . Dua Lokasi ini masih terdiri dari beberapa tempat yang berbeda. Di Boyololai ada tempat yang menjadi fokus penelitian yatu di Wonosegoro. Di desa ini ada beberapa KSM dan kordinatornya, setiap satu bulan sekali diadakan pertemuan kader dan aktivis LKTS datang ke tempat ini, pada saat usai pertemuan inilah penulis melakukan wawancara. Selain wawancara konteks tempat dan waktu yang terjadi menjadi bahan penting untuk melakukan penulisan. Untuk tempat penelitian kedua, yaitu LPS penulis melakukan di KSM ketika aktivis LPS usai memberikan pendampingan kepada petani anggota KSM. Selain mendapatkan data primer dari hasil wawancara mendalam, penulis juga mendapakan data-data sekunder berupa laporan perkembangan KSM, profil, dan prestasi yang sudah dimiliki oleh KSM.

Penelitian ini dilakukan dalam waktu 6 (enam) bulan. Tepatnya 4 (empat) bulan di LKTS dan 2 (dua) bulan di LPS. Penelitian di LKTS lebih lama karena selain tempatnya yang jauh, periode pertemuan yang dilakukan oleh KSM juga lebih lama (1 bulan sekali). Di LPS penelitian lebih singkat karena lokasi yang lebih dekat dan jarak pertemuan KSM lebih pendek. Penelitian ini dilakukan pada bulan Januari Juni 2008. Penelitian dilakukan setelah bekal proposal, ijin penelitian, dan pedoman penelitian termasuk pedoman pertanyaan sudah disiapkan. 


\section{Unit Analisis}

Unit analisis studi ini adalah Lembaga Swadaya Masyarakat (LSM) yang bergerak pada masyarakat akar rumput di Indonesia. LSM yang dipilih adalah Lembaga Kajian untuk Transformasi Sosial (LKTS) di Boyolali Jawa Tengah dan Lembaga Pertanian Sehat (LPS) di Bogor dan Sukabumi. Dua LSM ini mewakili tipologi berbeda kaitannya dengan keragaan donor dimana LKTS lebih banyak mendapatkan donor asing sedangkan LPS lebih banyak mendapatkan donor dari masyarakat lokal, LKTS mendapat dana dari lembaga donor internasional dan nasional, LPS memperoleh dana masyarakat melalui pendayagunaan Zakat, Infaq, Shadaqoh dan Wakaf (ZISWAF). LKTS berskala lokal-regional dan LPS berskala lokal, dua LSM ini juga memiliki sistem pendaan yang berbeda. Perbedaan sistem pendanaan LSM akan memberikan gambaran hubungan yang berbeda antara LSM dan lembaga donor. Struktur hubungan antara donor dan LSM inilah yang akan menjadi pembahasan independensi LSM. Independensi LSM diposisikan sebagai variabel dependen sementara kekuatan lembaga donor merupakan variabel independen.

\section{Strategi Penelitian}

Independensi LSM sebagai variabel dependen berhadapan dengan pengaruh kepentingan donor akan ditelaah dalam sub variabel finansial, aksi dan orientasi ideologi LSM. Untuk menjawab pertanyaan pada aspek finansial, aksi, dan ideologi metode yang lebih tepat adalah menggunakan metode kualitatif. Metode ini secara epistemologi, bisa meng-investigasi jejaring LSM dan kepentingan yang sebenarnya diperjuangkan secara lebih valid. Selain itu, metode ini dipilih karena relevansinya dengan perumusan masalah yang penulis ajukan, dimana aspek pengaruh donor dan perubahannya kepada LSM perlu dilihat sebagai gejala yang dinamis.

Strategi ini juga relevan dengan fokus kajian penulisan, dimana aspek finansial dilihat dari proporsi dana yang ada di LSM. Untuk masalah ini data sekunder diperlukan untuk melihat angka-angka-nya, tidak berhenti samapai disitu, pendalaman atas pertimbangan, ide dan pikiran dengan angka-angka tersebut menjadi penting dan diperlukan strategi untuk menggalinya. Begitu juga pada aspek aksi dan lebih khusus lagi pada aspek orientasi ideologi.

\section{Teknik Pengolahan dan Analisa Data}

Penelitian ini diawali dengan penggalian data, baik sekunder maupun primer. Peneltian di LKTS dilakukan di kantor LSM dan dilapang. Peneliti melakukan wawancara berdasarkan daftar pertanyaan yang telah dibuat sebelum turun lapang dilakukan (Lampiran 1.), wawancara dilakukan bersama kordinator-kordinator wilayah Boyolali, Klaten, Semarang dan Sukoharjo. Peneliti juga melakukan wawancara bersama kader 4 (empat) KSM di Wonosegoro Boyolali beserta dengan anggotanya. Selain wawancara, dilakukan studi dokumen dan publikasi yang dimiliki oleh LKTS. Dokumen yang ada adalah laporan keuangan tahunan, laporan kegiatan, dan laporan hasil evaluasi. Media publikasi juga dipelajari sebagai bahan memperkuat data, antara lain buletin pelita, press release, leaflet dan website. Dari bahan-bahan inilah peneliti mengungkap profil LSM mulai dari aspek kesejarahan, visi lembaga, kegiatan, struktur organisasi, aspek finansial, hingga evaluasi dari evaluasi lapang hingga evaluasi dilingkup pimpinan. Hal yang sama peneliti lakukan untuk LPS, karena lokasinya lebih dekat (Bogor) peneliti lebih banyak berinteraksi 
baik langsung maupun lewat kegiatan-kegiatan yang dilakukan. Sebelum penelitian ini dilakukan baik kepada LKTS maupun LPS telah terjalin hubungan komunikasi, sehingga untuk penambahan data, konfirmasi, dan koreksi kadang dilakukan dengan media telepon/HP. Cara seperti ini dilakukan setelah penelitian ini (pada enam bulan awal) selesai dilakukan. Sehingga data yang didapatkan dapat dengan mudah ditambah, dikonfirmasi dan mendapat respon dari aktivis LSM.

Data-data tersebut dicatat dalam catatan harian, catatan harian merupan data kunci dari buah pikiran narasumber yang diwawancara yang merupakan refleksi dari fakta dilapang. Kemudian dilakukan pengkodean sesuai dengan topik, pengkodean ini merupakan proses klasifikasi data dengan kebutuhan penelitian. Pada penelitian ini, data diklasifikasikan berdasarkan fokus kajian, untuk kemudian divisualisasikan dalam bentuk diagram untuk menggambarkan jaringan, tabel menunjukkan angkaangka yang berhubungan dengan fokus kajian, matriks dan kutipan pernyataan subyek penelitian untuk menggambarkan pandangan subyek.

Sebelum ditarik kesimpulan tetap, ada verifikasi hingga tercapai intersubyektifitas dan penelitian ini tidak untuk menarik generalisasi. Kesimpulan penelitian dihasilkan dengan mengalisa data yang tersedia sesuai dengan fokus kajian. Bentuk analisa dalam penelitian ini menggunakan pijakan teori yang akan dieksplorasi pada tinjauan pustaka. Hasilnya, kesimpulan yang ditarik merupakan hasil analisa teoritik dan fakta di lapang, dan disajikan kembali dalam bentuk tertulis dan untuk memberikan gambaran lebih baik disajikan dalam bentuk tabel, matriks dan kutipan wawancara. Untuk menjelaskan alur metodologi penelitian

\section{PEMBAHASAN}

\section{ANALISIS SISTEM PENDANAAN (ASPEK FINANSIAL) LSM}

Menurut Fakih (2000) LSM mengalami ketergantungan yang cukup kuat terhadap lembaga donor. Sebagaimana diketahui bahwa sejak munculnya organisasi nonpemerintah, yang di Indonesia populer dengan istilah LSM, pada awal 1970, sangat tergantung hibah dari berbagai lembaga donor internasional seperti USAID, FNS, NOVIB, dll. Selain itu, dalam beberapa kegiatan, LSM juga menerima bantuan dana dari lembaga keuangan internasional seperti Bank Dunia dan Asian Development Bank. Dana yang diterima oleh LSM dari sumber terakhir ini ada yang bersifat hibah, ada pula yang bersifat hutang negara.

Apapun bentuknya menurut Uhlin (1997), dana bantuan, baik hibah ataupun hutang negara banyak menimbulkan persoalan. Persoalan pertama dana seperti ini terbukti menimbulkan ketergantungan bagi organisasi. Di awal 1970 hingga saat ini, hibah luar negeri mengalir deras. Sehingga oleh sebagian kalangan dianggap sebagai sumber daya yang mudah didapatkan (easy money). Akibatnya, para pengurus organisasi non-pemerintah terbiasa menggantungkan seluruh kegiatan yang dilakukannya pada hibah luar negeri. Padahal belajar dari berbagai pengalaman, pendanaan yang bersumber dari hibah luar negeri tidak dapat diandalkan keberlanjutannya. Persoalan kedua, dana asing tidak bisa membuat organisasi lokal dapat melakukan program sesuai dengan kebutuhan spesifik. Selama ini yang terjadi adalah organisasi lokal selalu mengikuti arah keinginan pemberi dana (donor driven). 


\section{Sumber Dana LSM}

Dana memainkan peranan penting bagi hidup mati LSM. Untuk kebutuhan pelaksanaan kegiatan aksi, operasional, gaji, dan lainnya tentu membutuhkan dana segar. Oleh sebab itu, LSM selalu menempatkan pendaaan sebagai bagian utama dari eksistensi lembaga. Dana juga menjadi penentu keberlangsungan perjalanan aktivitas LSM, sehingga bagi 'pemiliknya' keberlangsungan dana menjadi bagian yang dipikirkan.

LKTS dan LPS mempunyai sistem sumber pendanaan yang berbeda. LKTS lebih banyak menggunakan dana donor asing (88 persen) dari pada sumber yang lain. Sementara LPS 96 persen dana diperoleh dari derma sosial lokal dalam bentuk Zakat, Infaq, Shadaqah, dan Wakaf (ZISWAF) selebihnya adalah hasil dari produksi hasil penelitian yang dijual secara komersial.

Tabel. Perbandingan Sumber Dana LKTS dan LPS (Persentase)

\begin{tabular}{|l|l|c|c|c|}
\hline NO & Nama LSM & Dana Asing (\%) & Dana Lokal (\%) & Dana Lainnya (\%) \\
\hline 1 & LKTS & 88 & 14 & 1 \\
\hline 2 & LPS & 0 & 96 & 4 \\
\hline
\end{tabular}

Sumber: Data diolah dari data sekunder (2008)

Dari penjelasan diatas dapat disimpulkan bahwa LKTS lebih tergantung secara pendanaan dengan donor asing (international agencies), dan LPS lebih tergantung dengan donor lokal (local agencies). Penelitian ini mengungkapkan ada keterkaitan antara independensi dibidang finansial terhadap aksi LSM di lapang. Sumbersumber dana yang memuat kepentingan donor memberikan pengaruh pada kinerja LSM. Besarnya pengaruh juga ditentukan oleh kemapanan LSM baik dalam bidang finansial, militansi ideologi, dan track record kinerja LSM. LKTS dengan sumber pendanaan yang didominasi oleh donor asing memiliki ketergantungan yang lebih tinggi pula terhadap donor dalam aspek aksi. Sedangkan LPS dengan sumber pendanaan lokal relatif tidak tergantung dengan kepentingan donor dalam aspek aksi.

Penjelasan pada aspek ketergantungan aksi maupun ideologi akan dibahas pada bab selanjutnya. Bab ini hanya ingin menunjukkan bahwa kedua LSM berbeda dalam sumber pendanaan. Perbedaan sumber pendanaan baik asing-maupun lokal akan dibahas secara garis besar pada Sub Bab 5.3 sedangkan pembahasan detailnya akan disajikan pada BAB VI pada penjelasan aksi LSM.

\section{Pengelolaan, Monitoring dan Evaluasi}

Pengelolaan dan monitoring antara LKTS dan LPS agak berbeda dalam pelaksanaan kegiatan. LKTS mempunyai variasi kegiatan yang berupa kegiatan yang terikat dengan donor dan kegiatan yang tidak terikat oleh donor. Sehingga untuk kegiatan yang terikat dengan donor, pengelolaan bersifat baku, sedangkan kegiatan yang bersifat tidak terikat lebih bebas. Berbeda dengan LPS yang tidak mengenal donor terikat dan tidak terikat. Bagi LPS dana yang ada adalah dana kegiatan yang akan dilaporkan, sehingga perencanaan pedanaan menjadi penting, tetapi juga memungkinkan adanya keluwesan saat pelaksanaan. 
Aspek keberlanjutan pendanaan juga menjadi perbedaan dari dua LSM ini. LKTS dengan dominasi donatur asing dalam kerangka proyek lebih terikat dengan pengelolaan dan pelaporannya, hal ini untuk keberlangsungan dan kepercayaan donor. Berbeda bagi LPS, keberlangsungan dana justru dilakukan di awal dengan kordinasi Dompet Duafa, dengan mengandalkan dana ZISWAF dengan konsekwensi yang lebih luwes.

Matriks. Pengelolaan Dana LSM

\begin{tabular}{|l|l|rl|c|}
\hline NO & Nama LSM & & Pengelolaan & \multicolumn{2}{c|}{ Publikasi Laporan keuangan } \\
\hline 1 & LKTS & $\bullet$ & $\begin{array}{l}\text { Terikat Donor, } \\
\text { Kreatifitas LSM }\end{array}$ & $\bullet$ \\
\hline 2 & LPS & $\bullet$ & Kreatifitas LSM & $\bullet \quad$ Umum \\
\hline
\end{tabular}

Sumber: Data diolah dari data sekunder (2008)

Dari Matriks 1. di atas dapat dilihat bahwa pengelolaan dana LKTS dilakukan dengan keterikatan pada donor dan kreatifitas LSM. Publikasi laporan keuangan LKTS dilakukan secara terbatas dan untuk umum. Pengelolaan dana LPS dilakukan dengan kreatifitas mereka dan terbuka untuk umum.

\section{Adaptasi keberlangsungan LSM dalam Pendanaan}

Usaha untuk mempertahankan dan meningkatkan sumber pendanaan bagi LSM menjadi agenda penting. Kegiatan ini dilakukan untuk menjaga keberlangsungan LSM itu. Baik LKTS maupun LPS melakukannya secara intensif. Persamaannya adalah kegiatan-kegiatan alternatif untuk penggalangan dana. LKTS cenderung berorientasi pada mempertahankan dan menambah donor asing sementara LPS meningkatkan edukasi publik untuk mempertahankan dan menambah kesadaran berderma.

Matriks Strategi LSM menjaga keberlangsungan Dana

\begin{tabular}{|l|l|l|l|}
\hline No. & $\begin{array}{c}\text { Nama } \\
\text { LSM }\end{array}$ & \multicolumn{1}{|c|}{ Strategi } & \multicolumn{1}{c|}{ Kegiatan } \\
\hline 1 & LKTS & $\begin{array}{l}\text { Mengembangkan Jaringan } \\
\text { Dana }\end{array}$ & Tender proyek, pengajuan program \\
\hline & $\begin{array}{l}\text { Diversifikasi bidang garapan } \\
\text { LSM }\end{array}$ & Membentuk sub bidang aktivitas \\
\hline & $\begin{array}{l}\text { Mempertahankan Donatur } \\
\text { Memperbaiki/mempertahankan } \\
\text { servis })\end{array}$ & Laporan berkala \\
\hline & & Surplus Kredit Mikro & Surplus perguliran dana KSM \\
\hline 2 & LPS & Investasi & Pembiayaan Mikro \\
\hline & & Perluasan Jaringan & $\begin{array}{l}\text { Direct mail, publikasi media massa, } \\
\text { membership, special event }\end{array}$ \\
\hline & & Produksi dan Bisnis & Perdirian Outlet di Mall, Swalayan, dll \\
\hline & & $\begin{array}{l}\text { Penelitian dan pemasaran produk } \\
\text { teknologi pertanian dan hasil pertanian } \\
\text { organik }\end{array}$ \\
\hline
\end{tabular}

Sumber: Data diolah dari data sekunder (2008) 
Dari Matriks 2. di atas dapat dilihat bahwa strategi LKTS dalam menjaga keberlangsungan dana adalah dengan mengembangkan jaringan dana, diversifikasi bidang garapan LSM, mempertahankan donatur (memperbaiki/mempertahankan servis), surplus kredit mikro dan investasi. Kegiatan yang diimplementasikan dari strategi tersebut adalah berupa tender proyek dan pengajuan program, membentuk sub sidang aktivitas, laporan berkala dan surplus perguliran dana KSM serta pembiayaan mikro. Strategi LPS dalam menjaga keberlangsungan dana adalah dengan kampanye publik, perluasan jaringan serta produksi dan bisnis. Kegiatan yang diimplementasikan dari strategi tersebut adalah direct mail, publikasi media massa, membership dan special event, perdirian outlet serta penelitian dan pemasaran produk teknologi pertanian dan hasil pertanian organik.

\section{ANALISIS AKSI LSM LKTS DAN LPS}

Pembahasan mengenai aksi LSM dalam tulisan ini akan dibagi dalam 3 kategori, yaitu inisiasi program aksi, pelaksanaan dan monitoring program. Dari analisis inisiasi, pelaksanaan dan monitoring program bisa dilihat independensi pada aspek aksi ini. Aspek aksi akan menggambarkan perjalanan dinamika LSM dalam bentuk aksi riil ditengah komunitas. Pembahasan mengenai aksi LSM tidak lepas dari pembahasan bab sebelumnya (BAB V) sehingga akan terjawab hubungan porsi sumber keuangan (independensi finansial) dengan independensi aksi.

LSM dalam memulai kegiatan dengan masyarakat akan menetapkan apa yang akan dikerjakan fase inilah yang disebut inisiasi. Inisiatif kegiatan akan menunjukkan seberapa besar partisipasi masyarakat, LSM dan intervensi donor. Begitu juga dalam fase pelaksanaan dan monitoring, dua fase ini menggambarkan kekuatan donor dalam proses pelaksanaan program dan evaluasi. Bentuk intervensi dalam pelaksanaan dapat diperlihatkan melalui petunjuk teknis pelakanaan, pada fase evaluasi dapat dilihat sejauh mana evaluasi dan monitoring suatu program bebas dari kekuatan intervensi donor. Pembahasan dalam bab ini akan memberikan penjelasan yang memadai mengenai dinamika kepentingan baik dari LSM maupun donor. Dinamika yang terjadi antara LSM dan donor dalam aspek ini akan memperjelas pembahasan pada bab analisis finansial BAB V.

Sebagian besar inisiasi program dilakukan oleh donor. Untuk pelaksanaan program sebagian diatur oleh donor dan sebagian independen dilaksanakan oleh LSM. Sebagian besar monitoring melibatkan lembaga independen. Proses monitoring dan evaluasi lebih banyak mendapat intervensi dari donor. Dalam pelaksanaan aksi, LKTS lebih banyak tergantung secara finansial, dan pada tataran aksi juga tergantung kepada donor. Di antara beragam program, Penguatan Ekonomi Mikro merupakan salah satu program LKTS yang berkelanjutan, mulai 2001 hingga 2009 kegiatan ini mendapatkan support dana sampai sekarang.

Kegiatan yang dilakukan oleh LPS baik dari proses, inisiasi, pelaksanaan hingga evaluasi tidak terikat dengan donor. LPS bebas untuk menentukan arah kegiatan selama masih pada bidang pertanian organik yang menjadi fokus dari kegiatan LSM ini. LPS juga tidak terlalu berkepentingan kepada donor untuk memberikan evaluasi atas kinerja LSM ini. Kegiatan penelitian, pengembangan masyarakat dan kegiatan produksi-bisnis muncul karena kebutuhan LSM. tiga kegiatan ini lebih bersifat rangkaian kegiatan yang semakin besar tetapi tetap pada visi awal, yaitu memajukan pertanian organik. Garis besar tujuan itulah yang menjadi syarat donor memberikan 
dananya. Kegiatan inisiasi, pelaksanaan hingga monitoring bebas ditentukan oleh LPS. Dari Matriks 5. dapat diketahui bahwa inisiasi, pelaksanaan dan monitoring program LPS sebagian besar dilakukan oleh LPS bersama masyarakat. Program LSM dimulai dari 1998 hingga 2008. Seluruh program LPS berlangsung hingga 2008. Matriks ini juga menunjukkan intervensi donor yang tidak besar. Kepentingan donor juga dirasakan tidak besar dalam kegiatan yang dilakukan oleh LPS.

Uraian program LSM yang telah dibahas menunjukkan adanya perbedaan antara LKTS dan LPS baik dalam inisiasi, pelaksanaan, muapun monitoring program. Pada aspek inisiasi, LKTS lebih banyak mengambil ide program dari lembaga donor. Sedangkan LPS lebih banyak mengambil ide dari visi LSM dan masyarakat. Pada aspek pelaksanaan kedua LSM merealisasi program dengan secara mandiri bersamasama masyarakat, dan pada aspek monitoring, hasil dan evaluasi dari program tergantung dari mana kepentingan dana dan insiasi berasal. Oleh sebab itu, monitoring hasil aksi LKTS lebih banyak oleh lembaga donor sedangkan LPS lebih banyak dilakukan oleh LSM sendiri dan hasilnya dilaporkan kepada masyarakat sebagai pertanggungjawaban.

Kondisi ini menunjukkan, bahwa LSM dengan sistem pendanaan lembaga donor memiliki ketergantungan lebih besar dibanding dengan LSM dengan sistem pendanaan masyarakat. Inisiasi aksi LSM LKTS lebih terbatas dibandingkan dengan LPS. Begitu juga pada aspek keberlanjutan program yang dilakukan. LKTS memiliki program yang beragam tetapi bersifat lebih pendek dan terikat dengan lembaga donor (Donor Driven). Sedangkan LPS program lebih berkesinambungan (Mission Driven).

\section{DINAMIKA INDEPENDENSI LSM DI TENGAH KEPENTINGAN DONOR}

Masalah penelitian yang ingin dijawab adalah ingin memahami sejauhmana kepentingan donor memberi pengaruh pada independensi LSM (merujuk pada platform berdirinya LSM) dan mengetahui sejauh mana perubahan pergeseran kepentingan donor mempengaruhi independensi LSM. Pada aspek finansial terdapat kesimpulan bahwa LSM menempatkan pendanaan sebagai persoalan utama bagi aksi yang akan dilakukan dan LSM yang menggunakan dana dari lembaga donor, lebih tergantung dibandingkan dengan LSM yang menggunakan dana masyarakat.

LSM melakukan upaya-upaya untuk melanggengkan sumber-sumber pendanaan yang sudah ada, melakukan pencarian sumber-sumber baru, bahkan LSM juga berusaha secara mandiri aktif melakukan usaha-usaha profit. Ciri ini nampak pada dua LSM ini. Perbedaannya adalah siapa yang menjadi target sumber-sumberdana. LKTS lebih memprioritaskan penggalian sumberdana dari donor asing, sedangkan LPS lebih banyak menggali dari sumber-sumber dana masyarakat. Dua strategi ini menghasilkan arah yang berbeda, LKTS lebih tergantung kepada lembaga-lembaga donor yang tidak bebas kepentingan, sedangkan LPS dengan dana masyarakat cenderung tidak tergantung dengan kepentingan atas dana yang dikumpulkan. DM (35) aktifis lapang LPS mengungkapkan, bahwa dana masyarakat cukup potensial untuk pengembangan lembaga-lembaga swadaya dan pengembangan komunitas. Berikut kutipan wawancaranya: 
LPS tidak begitu kesulitan dalam hal pendanaan, DD Republika mempunyai track record yang baik dalam menggalang dana. Akuntabilitas DD Republika selalu di laporkan dalam bulletin, booklet, web dan laporanlaporan langsung kepada donatur. Donatur DD Republika meningkat dari tahun ke tahun, hal ini bisa dilihat dari tren Zakat, Infaq dan Shodaqoh yang masuk ke DD Republika. Kegiatan THK (Tebar Hewan Kurban) bisa menjadi cermin yang ideal sistem pendananaan yang cukup baik.

SH (45) aktifis LKTS bidang pengembangan sosial ekonomi mengungkapkan bahwa LKTS sulit untuk keluar dari lingkaran kekuasaan donor, sebagai berikut:

Kami pada awalnya memang ingin dalam jangka menengah dan panjang untuk mandiri dari pendanaan funding. Baik itu lewat pendanaan dari masyarakat secara partisipatif atau usaha mandiri. Tapi bagi kami itu sulit, untuk cara pertama, LKTS tidak memiliki basis donatur lokal dari awalnya, agak beresiko juga kalau kami banting stir untuk sumber dana, jadi pilihan untuk mencari donatur lokal secara partisipatif agak sulit. Pilihan kedua juga kami rasa agak sulit, kami aktivis, bukan wirausaha, memang beberapa donor juga ada program mandiri dimana LSM dalam jangka panjang lewat usaha-usaha mikro bisa mengelola masyarakat untuk kedepannya, sehingga dari pemberdayaa masyarakat LSM bisa menjadi manajer dari usaha-usaha masyarakat itu, seperti menjadi agen distribusi usaha produksi. Hal ini sudah kami jalani, seperti menjadi fasilitator untuk penjualan furniture rotan, dan bebek, tapi masyarakat lebih berpengalaman dalam usaha-usaha ini. Terakhir, kami menakumulasi modal kredit mikro dan kami membuka semacam pembiayaan, ini sedang berjalan dan mekanisme-nya lebih mudah.

SH (45) aktifis LKTS bidang pengembangan sosial ekonomi juga menambahkan sebagai berikut:

LKTS pada saat berdiri memiliki aktivis hanya 5 (lima) orang, saat itu memang kita punya minat yang sama. Kita sama-sama aktivis di kampus dan menikmati pekerjaan sebagai aktivis LSM. Setelah LKTS membesar, mulai memerlukan lebh banyak aktivis, atau lebih tepatnya staf, karena mereka bekerja dengan jadwal kerja yang teratur, gaji, dan deskripsi kerja yang jelas. Aktivis direkrut berdasarkan keahlian tanpa harus mensyaratkan memiliki loyalitas terhadap aktivisme.

Awalnya tidak pernah terlintas LKTS akan menjadi lembaga yang mencari keuntungan atau menjadi lembaga bisnis. Tetapi perkembangan LKTS dengan banyaknya staf, biaya operasional dan kebutuhan-kebutuhan yang makin besar, maka kami juga harus memikirkan kemandirian. Untuk itulah kami mencoba untuk membuat usaha mandiri. Tetapi itupun sulit, LSM bukanlah lembaga bisnis, aktivisnya juga bukan para wirausaha, oleh karena itu LKTS juga pada posisi sulit pada titik ini. Kegiatan-kegiatan yang ada idak menghasilkan profit langsung. Untuk kegiatan kredit mikro kami memang ada porsi untuk profit LSM sebesar 0,5\% dari angsuran KSM tetapi itu sangat kecil, sehingga tidak kami jadikan sebagai solusi bagi kemandirian LSM. Kami berencana untuk membuka semacam pembiayaan mikro, ini adalah alternatif bagi anggota KSM untuk mendapatkan dana segar dengan interes yang tidak terlalu tinggi. Sejauh ini, paling tidak, kita sudah punya track record siapa saja anggota KSM yang dipercaya, cara seperti ini juga sudah kita 
laksanakan walaupun skalanya masih kecil, tapi kelak saya lihat ini cukup berpotensi sebagai salah satu sumber pendanaan LKTS.

Komitmen kami kepada masyarakat sebagai bagian dari proses ini adalah yang utama. Masyarakat adalah subjek dari pengembangan mereka. Perlu adanya kesadaran ini bagi para aktivisnya. Tetapi tidak semua aktivis LSM khususnya staf baru yang mempunyai kesadaran yang sama. Orientasi staf yang bekerja adalah penghasilan.

Kepentingan atas dana yang dikeluarkan berbeda antara dana dari masyarakat dan dana dari donor luar. DM (35) aktifis lapang LPS mengungkapkan mengapa orang memberikan dananya kepada LPS DD Republika, sebagai berikut:

Kesadaran adalah alasan paling kuat mengapa orang mengeluarkan ZISWAF, pemberian mereka sering tanpa pamrih, sehingga program marketing kami adalah menumbuhkan kesadaran untuk mengeluarkan ZISWAF baik dari pendekatan agama, kemanusiaan maupun pendekatan perasaan.

Penulis meyakini sumberdana LSM dalam penelitian ini, diakui tidak ada yang bebas akan kepentingan seperti pandangan Ufford dan Giri (2002). Yang berbeda adalah derajat kepentingan dari pemberi dana (donor) kepada LSM sebagai lembaga yang melakukan aksi. Dari penelitian ini diketahui bahwa dana dari lembaga donor asing, pemerintah asing, perusahaan dan pemerintah mempunyai kepentingan lebih tinggi dari pada dana dari masyarakat. Kepentingan ini ditunjukkan dengan banyaknya syarat yang diajukan oleh lembaga donor kepada LSM baik itu dari aspek inisiasi program, pelaksanaan dan monitoring-nya.

Pada titik inilah terjadi hubungan dinamis antara kebutuhan dana oleh LSM disatu sisi dengan misi yang ingin dijalankan oleh LSM disisi yang lain. Keragaan dinamika tersebut penulis gambarkan dalam matriks berikut ini.

Matriks Dinamika Sistem Pendanaan dan Ideologi LSM

\begin{tabular}{|c|c|c|c|c|}
\hline \multirow{3}{*}{$\begin{array}{l}\text { Orientasi } \\
\text { Ideologi }\end{array}$} & \multicolumn{4}{|c|}{ Sumber Dana } \\
\hline & \multicolumn{2}{|l|}{ Eksternal } & \multicolumn{2}{|l|}{ Internal } \\
\hline & Interest & $\begin{array}{c}\text { Non } \\
\text { Interest }\end{array}$ & Interest & $\begin{array}{c}\text { Non } \\
\text { Interest }\end{array}$ \\
\hline Selaras & Sinergi & - & Sinergi & - \\
\hline Tidak Selaras & $\begin{array}{l}\text { Dinamika: } \\
\text { 1. Re-orientasi ideologi, } \\
\text { 2. Distorsi Ideologi } \\
\text { (Negosiasi), } 3 \text {. } \\
\text { Penolakan atas dana }\end{array}$ & - & $\begin{array}{l}\text { Dinamika } \\
\text { 1.Re-orientasi ideologi } \\
\text { (Penyusupan Sukses) } \\
\text { 2.Negosiasi, } \\
\text { 3.Penolakan anggota } \\
\text { (dikeluarkan) }\end{array}$ & - \\
\hline
\end{tabular}

Sumber : Data Primer diolah, 2008

Matriks ini menunjukkan hubungan antara ideologi LSM (terkait dengan visi \& misi LSM) dengan sumberdana. Sumber dana dibagi menjadi 2 (dua) sumber yaitu eksternal LSM dan internal LSM, keduanya lantas dibagi menjadi 2 (dua) yaitu 
sumber-sumber dana yang mempunyai kepentingan dan sumber-sumber dana yang bebas kepentingan. Sementara pada aspek ideologi terdapat dua pembeda, yaitu dana-dana dari sumber yang tidak selaras dengan dana-dana dari sumber yang selaras. Dana dari sumber-sumber yang selaras dengan ideologi, visi misi dan kegiatan LSM akan membuat hubungan LSM dengan lembaga donor menjadi sinergis, sementara sebaliknya, jika terjadi ketidakselarasan ideologi, akan terjadi kemungkin-kemungkinan, yaitu re-ideologi, negosiasi, atau pada titik ekstrim terjadi penolakan dana oleh LSM dari lembaga donor.

Kondisi ini terjadi baik pada sumber-sumber dana ekternal maupun internal. Sumber-sumber dana eksternal bisa berasal dari pemerintah, perusahaan, masyarakat, donor asing, pemerintah asing, LSM lain baik dalam negeri maupun luar negeri. Sedangkan dana internal berasal dari individu yang berada di dalam lingkaran LSM. Hanya saja, bentuk ektrem dari penolakan dana dari individu bisa berupa pemecatan individu tersebut dari keanggotaan/kepengurusan LSM tersebut.

Pada saat terjadi ketidakselarasan antara LSM dengan sumberdana selain reideologisasi LSM dan penolakan. Ditengahnya ada proses negosiasi, dalam proses ini hal-hal yang mempengaruhi kekuatan negosiasi LSM adalah: 1. Militansi ideologi LSM, 2.Kemapanan LSM dalam dana, 3. Kemapanan Kinerja LSM (Prestasi LSM). Sumberdana terkadang pada posisi yang membutuhkan, sehingga 3 hal ini menjadi pertimbangan LSM bisa pada posisi ideologinya. Dinamika ideologi LSM dengan aksi yang dilakukan terjadi pada tiga titik, yaitu proses inisiasi program, pelaksanaan program dan monitoring/evaluasi program. Untuk menjelaskannya akan dijelaskan pada matriks di atas.

Hasil wawancara dengan SH (45) aktifis LKTS bidang pengembangan sosial ekonomi, merupakan refleksi perubahan orientasi LSM dari plaform awalnya. Kutipan wawancaranya sebagai berikut:

...Dalam perjalannya, LKTS semakin besar dan semakin banyak kegiatannya. Keadaan ini membuat kebutuhan organisasi makin meningkat. Kebutuhan staf meningkat dan akhirnya terakumulasi dengan kebutuhan dana yang juga meningkat. Hal inilah yang membuat kami semakin banyak memerlukan kepastian sumbersumber dana.

Pada kutipan di atas menunjukkan bahwa kepentingan dari dana yang ada terjadi baik pada sumber-sumber dana ekternal maupun internal. Sumber-sumber dana eksternal bisa berasal dari pemerintah, perusahaan, masyarakat, donor asing, pemerintah asing, LSM lain baik dalam negeri maupun luar negeri. Sedangkan dana internal berasal dari individu yang berada di dalam lingkaran LSM. Hanya saja, bentuk ektrem dari penolakan dana dari individu bisa berupa pemecatan individu tersebut dari keanggotaan/kepengurusan LSM tersebut.

Pada saat terjadi ketidakselarasan antara LSM dengan sumberdana selain reideologisasi LSM dan penolakan. Ditengahnya ada proses negosiasi, dalam proses ini hal-hal yang mempengaruhi kekuatan negosiasi LSM adalah:

1. Militansi ideologi LSM

2. Kemapanan LSM dalam dana 


\section{Kemapanan Kinerja LSM (Prestasi LSM)}

Sumberdana terkadang pada posisi yang membutuhkan, sehingga 3 (tiga) hal ini menjadi pertimbangan LSM bisa pada posisi ideologinya. Seperti kutipan wawancara bersama SH (45) aktifis LKTS bidang pengembangan sosial ekonomi berikut ini:

LSM dengan mudah bisa keluar dari lingkaran keinginan-keinginan donor apabila mempunyai prinsip yang kuat, tetapi prinsip yang kuat saja tidak menjamin LSM bisa hidup, kecuali memang pihak donor tidak terlalu berkepentingan dengan program kerja, tetapi ini jarang ada. LSM memerlukan kemandirian dana, saya kira LSM dengan sistem pendanaan mandiri lebih bisa mempunyai kekuatan untuk bernegosiasi, dan yang ketiga adalah kualitas kinerja LSM. Semakin bagus kualitas LSM, kinerjanya baik, pengalamannya bagus akan mempunyai posisi tawar yang lebih tinggi.

Kutipan di atas menunjukkan bahwa LSM memiliki posisi tawar yang lebih tinggi apabila memiliki keteguhan terhadap prinsip yang kuat, tidak saja itu, kemapanan finansial, dan kinerja LSM juga menjadi faktor penting. Kekuatan yang bersifat internal ini menjadi modal dalam proses negosiasi dengan donor.

LSM memiliki kedekatan dengan objek bagi pembangunan oleh pemerintah atau swasta, LSM juga memiliki aktivis yang bisa menelusup masuk secara lebih dalam tanpa atribut pemerintah dan swasta, memiliki fleksibilitas, dianggap tidak membawa kepentingan kekuasaan, dan memiliki pendekatan aksi yang lebih down to earth. Penulis menemukan, pada aspek pelaksanaan aksi inilah LSM cederung bisa independen. Lebih dari itu, keunggulan inilah yang dinilai oleh pemilik kepentingan untuk memanfaatkan keberadaan LSM. Seperti yang disebutkan oleh AG (45) aktifis LKTS bagian pengembangan internal, sebagai berikut:

"Kami masih eksis karena kami mempunyai karakter yang khas dalam metodologi pengembangan masyarakat, kami memiliki pendekatan yang tidak dimiliki oleh pemerintah, kami mampu masuk dalam suatu komunitas, mengorganisir mereka dan melakukan tujuan -tujuan tanpa prosedur yang nljimet dan birokratis"

\section{Pergeseran Orientasi Ideologi}

Sebagian besar literatur tetang LSM menjelaskan ciri-ciri sekaligus kekuatan lembaga ini sebagai agen yang bisa diharapkan menjadi alternatif pendekatan pembangunan, seperti yang dikemukakan oleh Sheperd (1998), Korten (1987) Hannam dalam Siregar (1988), maupun Fakih (2000). LSM sebagai lembaga yang memiliki kekuatan pada 2 (tiga) ciri utama non-komersialisme dimana LSM merupakan lembaga yang nirlaba atau nonprofit, dan populisme dimana LSM mempunyai keberpihakan kepada masyarakat sipil dengan tujuan untuk mencapai kesejahteraan.

Kedua ini LSM pada awal berdirinya memiliki ciri-ciri seperti yang disebutkan diatas. Pada perkembangannya, orientasi ideologi bergeser dengan tren lebih rendah. 
Seperti yang dikemukakan oleh SH (45) aktifis LKTS bidang pengembangan sosial ekonomi sebagai berikut:

LKTS pada saat berdiri memiliki aktivis hanya 5 (lima) orang, saat itu memang kita punya minat yang sama. Kita sama-sama aktivis di kampus dan menikmati pekerjaan sebagai aktivis LSM. Setelah LKTS membesar, mulai memerlukan lebh banyak aktivis, atau lebih tepatnya staf, karena mereka bekerja dengan jadwal kerja yang teratur, gaji, dan deskripsi kerja yang jelas. Aktivis direkrut berdasarkan keahlian tanpa harus mensyaratkan memiliki loyalitas terhadap aktivisme.

Awalnya tidak pernah terlintas LKTS akan menjadi lembaga yang mencari keuntungan atau menjadi lembaga bisnis. Tetapi perkembangan LKTS dengan banyaknya staf, biaya operasional dan kebutuhan-kebutuhan yang makin besar, maka kami juga harus memikirkan kemandirian. Untuk itulah kami mencoba untuk membuat usaha mandiri. Tetapi itupun sulit, LSM bukanlah lembaga bisnis, aktivisnya juga bukan para wirausaha, oleh karena itu LKTS juga pada posisi sulit pada titik ini. Kegiatan-kegiatan yang ada idak menghasilkan profit langsung. Untuk kegiatan kredit mikro kami memang ada porsi untuk profit LSM sebesar $0,5 \%$ dari angsuran KSM tetapi itu sangat kecil, sehingga tidak kami jadikan sebagai solusi bagi kemandirian LSM. Kami sedang menggalang sebuah usaha semacam pembiayaan mikro, ini adalah alternatif bagi anggota KSM untuk mendapatkan dana segar dengan interes yang tidak terlalu tinggi. Sejauh ini, paling tidak, kita sudah punya track record siapa saja anggota KSM yang dipercaya, cara seperti ini juga sudah kita laksanakan walaupun skalanya masih kecil, tapi kelak saya lihat ini cukup berpotensi sebagai salah satu sumber pendanaan LKTS.

Komitmen kami kepada masyarakat sebagai bagian dari proses ini adalah yang utama. Masyarakat adalah subjek dari pengembangan mereka. Perlu adanya kesadaran ini bagi para aktivisnya. Tetapi tidak semua aktivis LSM khususnya staf baru yang mempunyai kesadaran yang sama. Orientasi staf yang bekerja adalah penghasilan.

Atau ungapan dengan redaksi yang berbeda dikemukakan oleh FK (39) bidang perencanaan LKTS, sebagai berikut:

Dalam perjalannya, LKTS semakin besar dan semakin banyak kegiatannya. Keadaan ini membuat kebutuhan organisasi makin meningkat. Kebutuhan staf meningkat dan akhirnya terakumulasi dengan kebutuhan dana yang juga meningkat. Hal inilah yang membuat kami semakin banyak memerlukan kepastian sumbersumber dana.

Dari hasil wawancara diatas menunjukkan adanya pergeseran nilai-nilai nonkomersialisme dalam LSM. Pada aspek ini, LSM mengalami pergeseran, awalnya 
LSM sebagai lembaga yang murni menjadi inisiator pengembangan masyarakat. Karena faktor kebutuhan LSM yang makin besar, dan LSM perlu memastikan sumber-sumber dana. Maka LSM mulai mengembangkan usaha-usaha penggalangan dana alternatif. LKTS melakukan usaha pembiayaan kredit mikro. Kegiatan ini mirip dengan usaha pembiayaan bank konvensional hanya dengan bunga yang lebih rendah. Kegiatan pembiayaan mikro yang dilakukan juga menjadi indikasi memanfaatkan KSM yang ada sebagai objek dari kegiatan ini. Kondisi ini menggambarkan memudarnya populisme LKTS terhadap masyarakat. Begitu juga yang terjadi dengan LPS, awalnya LPS berdiri sebagai lembaga peneitian dan pengembangan masyarakat kemudian mulai bergeser setelah masuknya bidang produksi dan bisnis yang secara eksplisit adalah bentuk komersialisme LPS karena bertujuan profit baik menjadi distributr bagi produk dari masyarakat, memasarkan hasil penelitian untuk KSM maupun untuk pasar umum.

Kondisnya hampir sama dengan LKTS, LPS berawal dari kumpulan aktivis dengan visi yang sama. Setelah makin besar dengan kebutuhan SDM makin banyak dan beragam, LSM tidak lagi melihat visi aktivis sebagai dasar rekrutmen. Profesionalitas lebih menjadi dasar rekrutmen, sementara pada saat yang sama staf aktifis LSM lebih mengukur kinerja dengan gaji. Aktifis LSM tidak memandang visi sebagai dasar utama. Sebagai pekerja dengan deskripsi kerja yang jelas, waktu yang jelas, dan gaji yang jelas.

Masuknya ruh bisnis sejak tahun 2004, membuat LSM ini mengalami pergeseran keberpihakan. Awalnya LSM melakukan pengembangan masyarakat, kemudian dengan kegiatan bisnis, LSM menjadikan KSM sebagai pasar penjualan produk pupuk dan pestisida, LSM juga menjadi distributor produk hasil pertanian dari KSM. LSM juga menjadikan keberhasilan KSM sebagai komoditas iklan penjualan produk LPS kepada masyakat umum. Kondisi ini menunjukkan pergeseran orientasi populisme LSM. Seperti yang dikemukakan oleh AG (45) aktifis LKTS bidang pengembangan sosial ekonomi, sebagai berikut:

Setelah KSM terbentuk program pertanian organik mulai petani merasakan manfaat yang diperoleh, pertama modal untuk program ini memang dari LPS, didampingi oleh LPS dan hasilnya bisa dikembalikan kepada LPS untuk dijual atau petani yang menjual sendiri. Dari produk yang dihasilkan dan ternyata layak dipasarkan, Pada saat inilah LPS mulai mengembangkan bidang produksi dan bisnis kira-kira sejak tahun 2004. Program inilah yang diharapkan nanti bisa menopang sistem pendanaan di LPS. Alhamdulillah, program ini bisa menghasilkan profit bagi LSM. Kami bisa menjadi fasilitas penjualan untuk produk pertanian organik hasil KSM yang kami bina, kami juga bisa menjual pupuk, pertisida maupun benih kepada KSM dan karenahasilnya sudah terbukti, kami bisa menjualnya ke pasar umum.

Matriks di bawah ini menjelaskan adanya pergeseran orientasi ideologi LSM baik LPS maupun LKTS. Pada matriks ini, kedua orientasi ideologi ideal LSM (non komersialisme dan populisme) mengalami tren penurunan. Penurunan yang terjadi 
diakibatkan oleh perjalanan aksi LSM berdinamika dengan berbagai kebutuhan dan kepentingan. LSM dalam aspek orientasi non-komersialisme mengalami pergeseran dari LSM yang awalnya murni gerakan non-profit menjadi lembaga yang berusaha melakukan usaha mandiri (orientasi profit). Untuk kasus LKTS dengan membuka kegiatan kredit pembiayaan mikro sedangkan LPS terang-terangan melakukan usaha bisnis menjual produk penelitian kepada masyarakat dan menjadi distributor dari program KSM. Kegiatan yang bersifat profit dilakukan sebagai salah satu cara untuk mempertahankan keberlangsungan dana LSM. Kegiatan ini juga dimaksudkan untuk melepaskan diri dari ketergantungan finansial kepada donor.

Pergeseran orientasi ideologi yang dijelaskan diatas bisa digambarkan pada matriks berikut ini

Matriks Pergeseran Orientasi Ideologi Independensi LSM

\begin{tabular}{|c|c|c|c|c|}
\hline \multirow{2}{*}{$\begin{array}{l}\text { Orientasi } \\
\text { Ideologi }\end{array}$} & \multicolumn{2}{|c|}{ Awal } & \multicolumn{2}{|r|}{ Saat ini } \\
\hline & LKTS & LPS & LKTS & LPS \\
\hline \multirow[t]{2}{*}{$\begin{array}{l}\text { Non- } \\
\text { Komersialisme }\end{array}$} & $\begin{array}{l}\text { tidak ada } \\
\text { kegiatan } \\
\text { komersial } \\
\text { (berorientasi } \\
\text { profit) dalam } \\
\text { kegiatan } \\
\text { bersama } \\
\text { masyarakat. }\end{array}$ & $\begin{array}{l}\text { tidak ada } \\
\text { kegiatan } \\
\text { komersial } \\
\text { (berorientasi } \\
\text { profit) dalam } \\
\text { kegiatan } \\
\text { bersama } \\
\text { masyarakat }\end{array}$ & $\begin{array}{l}\text { Mulai ada } \\
\text { kegiatan } \\
\text { komersial } \\
\text { seperti surplus } \\
\text { kredit mikro, } \\
\text { pembiayaan } \\
\text { mikro }\end{array}$ & $\begin{array}{l}\text { mulai ada kegiatan } \\
\text { produksi dan bisnis. } \\
\text { Kegiatan ini } \\
\text { berorientasi pada } \\
\text { pemasaran produk } \\
\text { penelitian dan produksi } \\
\text { KSM. }\end{array}$ \\
\hline & \multicolumn{4}{|c|}{$\begin{array}{l}\text { Kesimpulan: Terjadi pergesaran dengan tren penurunan tingkat non- } \\
\text { komersialisme LKTS dan LPS. }\end{array}$} \\
\hline \multirow[t]{2}{*}{ Populisme } & $\begin{array}{l}\text { kegiatan } \\
\text { berorientasi } \\
\text { pada } \\
\text { peningkatan } \\
\text { kesejahteraan } \\
\text { masyarakat. }\end{array}$ & $\begin{array}{l}\text { kegiatan } \\
\text { berorientasi } \\
\text { pada } \\
\text { peningkatan } \\
\text { kesejahteraan } \\
\text { masyarakat. }\end{array}$ & $\begin{array}{l}\text { kegiatan } \\
\text { berorientasi } \\
\text { pada } \\
\text { peningkatan } \\
\text { kesejahteraan } \\
\text { masyarakat. } \\
\text { LSM } \\
\text { menjadikan } \\
\text { KSM sebagai } \\
\text { target pasar } \\
\text { lembaga } \\
\text { pembiayaan } \\
\text { mikro }\end{array}$ & $\begin{array}{l}\text { kegiatan berorientasi } \\
\text { pada peningkatan } \\
\text { kesejahteraan } \\
\text { masyarakat masih ada. } \\
\text { Tetapi mulai beralih } \\
\text { menjadi LSM yang } \\
\text { melakukan aktivitas } \\
\text { Bisnis dan } \\
\text { memanfaatkan KSM } \\
\text { sebagai konsumen } \\
\text { produk LSM. LSM } \\
\text { juga menjadi } \\
\text { distributor produk } \\
\text { KSM dengan orientasi } \\
\text { profit }\end{array}$ \\
\hline & \multicolumn{4}{|c|}{$\begin{array}{l}\text { Kesimpulan: Terjadi pergesaran dengan tren penurunan tingkat populisme } \\
\text { LKTS dan LPS }\end{array}$} \\
\hline
\end{tabular}

Sumber : Data primer diolah, 2008

Dalam hal populisme juga menurun, keberpihakan awal yang total diberikan kepada masyarakat pada perjalanannya melemah. Untuk LKTS, pada saat awal LSM memang melakukan aksi pengembangan masyarakat dengan perguliran kredit mikro. Dari kegiatan ini LSM bisa mendapatkan data siapa saja anggota KSM yang 
bisa dipercaya, dari sini ditawarkan dana untuk pemibiayaan (ekstra) dengan mekanisme angsuran dengan tambahan yang lebih besar dibandingkan dengan kredit mikro. Perbedaan antara kredit mikro dengan kredit pembiayaan, adalah pada besarnya dana yang bisa dipinjam, jika kredit mikro berkisar antara Rp 500.000,maka pembiayaan mikro bisa antara Rp 1.000.000,- hingga Rp 5.000.000,- . Fakta ini menunjukkan terjadi pergesan nilai-nilai populisme LSM. LPS pada awalnya menjadikan KSM sebagai bagian yang melakukan uji coba produk dan diberikan pupuk, pestisida dan benih secara cuma-Cuma. Pada perkembanannya KSM menjadi membeli produk-produk tersebut walaupun dengan harga dibawah pasar. LSM dengan pengalaman KSM sebagai media ujicoba bisa menjual produknya ke pasar dengan dasar kisah sukses yang dialami oleh KSM. LSM juga mendapatkan banyak pengalaman lapang mengenai produk-produk hasil penelitiannya. Fakta ini menunjukkan adanya pergeseran keberpihakan dan kondisi memanfaatkan KSM untuk laboratorium lapang. Sehigga LPS bisa berkembang dengan menjadikan KSM sebagai pasar, menjadikan KSM sebagai produsen, dan KSM sebagai laboratorium lapang.

Pada Matriks 8. memperlihatkan bahwa komitmen LSM makin rendah terhadap masyarakat, memperlihatkan juga bahwa aspek non-komersialisme LSM makin meluntur. Hal ini disebabkan karena perkembangan LSM membawa akibat makin besarnya LSM, konsekwensinya bagi LSM adalah meningkatnya jumlah staf, operasional dan kebutuhan lainnya. Dalam kasus LSM tidak ada dana yang bersifat abadi, bahkan proyek-proyek yang dilaksanakan oleh LKTS adalah proyek-proyek jangka pendek. Sehingga LSM perlu mengembangkan strategi pendanaan yang dibahas pada Bab V.

\section{Independensi LSM}

Akhirnya independensi LSM dalam penelitian ini bila dilihat dari aspek finansial LSM, aksi LSM kaitannya dengan orientasi ideologi LSM. Bagi LSM, orientasi ideologi yang dimaksud adalah non-komersialisme (LSM sebagai lembaga nirlaba/non profit) dan keberpihakan pada masyarakat sipil (populisme). Hasil analis pada Bab V mengenai aspek finansial LSM menunjukkan bahwa LKTS sebagai LSM yang lebih banyak menerima dana dari donor asing (lihat kembali Tabel. 1) sulit untuk keluar dari lingkaran kepentingan donor. Hal ini ditunjukkan dengan pengelolaan dan monitoring dana yang terikat dengan kepentingan pihak donor (lihat kembali Gambar 5.) Demikian juga pada aspek Aksi, inisiasi, aksi dan monitoring program kegiatan tidak bisa dilepaskan dari kepentingan donor (lihat kembali Matriks 3.) yang menunjukkan besarnya pengaruh donor pada 3 tahapan aksi LKTS. Seperti juga yang diungkapkan oleh SH (45) aktifis LKTS bidang pengembangan sosial ekonomi, sebagai berikut:

...Idealnya kegiatan-kegiatan LKTS memang berasal dari masyarakat, tapi memang sulit untuk memilah aspek inisiasi ini, pertama program dari donor biasanya sudah spesifik...

... Pertanggung jawaban atas dana memang sangat ketat, karena menyangkut pencairan dana. Biasanya, untuk sebuah program uang tidak cair semua-nya di awal, ada termin-termin pencairan yang membuat kami harus jeli membuat target kegiatan, untuk awal 
program biasanya kami mendapatkan 30\%, $30 \%$ apabila progress kegiatan sudah mencapai setengahnya dan diakhir program dengan laporan kami baru bisa mencairkan 40\%-nya. Bagi kami degan mekanisme seperti ini perlu juga dana talangan, atau modal kalau perusahaan. Karena dana yang kegiatan seringkali tidak cair di awal kegiatan, bahkan kadangkala harus menunggu 3 tiga sampai 6 bulan kemudian. Ini juga menjadi kendala bagi kinerja LSM, karena LSM harus patuh pada prosedur donor, bahkan juga alur kerja donor...

...Seperti LSM yang lain, LKTS memiliki keunggulan aksi yang dekat dengan masyarakat, kita sering membangun kegiatan dengan kelompok masyarakat secara langsung. Tetapi ada beberapa kegiatan yang sudah jelas petunjuk-nya, tahapan programnya, wilayah, objek, sampai pada target-target yang harus dipenuhi...

...Dalam beberapa program kami mempunyai kewajiban memberikan laporan secara berkala, laporan perencanaan, on going report, dan laporan hasil, sebenarnya laporan tersebut adalah syarat pencairan dana dari donor. Yang biasnya terdiri dari termin-termin. Tetapi untuk program yang tidak terikat kontrak, untuk pelaporan lebih fleksibel. Setiap tahun LKTS juga diaudit oleh auditor independen, biasnya auditor hasil audit ini menjadi semacam profil kepentingan LSM, kalau track record auditnya bagus, maka sebuah LSM akan lebih mudah mendapatkan dana...

Penjelasan di atas menunjukkan besarnya pengaruh donor terhadap kinerja LKTS. Kondisi ini sulit dihindari karena ketergantungan dana terjadi seiring dengan perkembangan LKTS yang makin besar dengan kebutuhan yang semakin besar juga. Pada aspek idelogi, LKTS mengalami pergeseran orientasi ideologi karena kebutuhan yang semakin besar akan staf dengan keahlian tertentu, jaminan kebutuhan dana sehingga masyarakat yang menjadi alternatif yang dapat memenuhi tuntutan kebutuhan tersebut, dengaan menjadikan mereka konsumen dari produk jasa pembiayaan oleh LSM.

Bagi LPS dengan sumber dana donor lokal lewat ZISWAF (lihat Tabel 2. Dan Gambar 4.), menghasikan bentuk yang berbeda. Baik pada pengelolaan maupun monitoring dilakukan oleh LSM bukan oleh donor. Pada aspek aksi, pihak donor tidak melakukan intervensi pada tahap inisiasi, aksi maupun monitoring. Kondisi ini menyebabkan LPS dalam pelaksanaan kegiatan lebih bebas. (lihat Gambar 6. dan Matriks 3.), seperti yang diungkapkan oleh SJ (43) kordinator bidang pengembangan masyarakat LPS, sebagai berikut:

...LPS tidak begitu kesulitan dalam hal pendanaan, DD Republika mempunyai track record yang baik dalam menggalang dana. Akuntabilitas DD Republika selalu di laporkan dalam bulletin, booklet, web dan laporan-laporan langsung kepada donatur. Donatur DD Republika meningkat dari tahun ke tahun, hal ini bisa dilihat dari tren Zakat, Infaq dan Shodaqoh yang masuk ke DD Republika. Kegiatan THK (Tebar Hewan Kurban) bisa menjadi cermin yang ideal sistem pendananaan yang cukup baik... 
...Pernah kami menerima tawaran untuk melakukan proyek yang didanai oleh lembaga donor. Tapi kami tidak berminat, alasannya, karena prosedurnya yang rumit dan terkesan memaksa. Kami harus membuat semacam proposal untuk diajukan, kemudian proposal itu dipilih, karena kita harus bersaing dengan LSM lain, dari sana ada syarat-syarat yang perlu dipenuhi baik pada aspek perencanaan, pelaksanaan dilapang dan laporannya juga diawasi ketat. Bagi kami, cara demikian kurang sesuai dengan semangat yang kami bangun selama ini...

...LPS dalam perkembangannya bebas menentukan arah kegiatan, kami memilih untuk membuat rencana yang berkesinambungan sehingga hasilnya lebih kuat. Pertama basis penelitian, dilanjutkan dengan pengembangan masyarakat dan dilanjutkan dengan kegiatan produksi dan bisnis. Kegiatan produksi dan bisnis adalah usaha kami untuk mandiri secara finansial, dalam jangka panjang, kegiatan ini akan menjadi sumber utama dana bagi LPS..

Penjelasan diatas menunjukkan bahwa ketersediaan dana yang dihimpun dari donatur lokal lewat ZISWAF memberikan keleluasaan bagi LPS untuk mengelola dan mengevaluasi dari guliran dana. Donor dalam hal ini masyarakat yang memberikan dana-dana ZISWAF mempercayakan sepenuhnya pengelolaan dana kepada lembaga ini. Sehingga walaupun sumber dana bukan sumber dana mandiri, LSM bisa sepenuhnya mengelola dan mengevaluasi perguliran dana tersebut. LPS dalam aspek aksi memiliki kebebasan untuk menentukan ide program (inisiasi), pelaksanaan, dan monitoring kegiatan secara penuh bersama-sama dengan KSM, donatur mempercayakan aspek ini kepada LPS. Kepercayaan inilah yang membuat LPS bebas menentukan strategi aksi baik dari inisiasi, pelaksanaan hingga pelaporan. Faktor ini yang membuat LPS lebih berkesinambungan dan fokus kepada tujuan yang hendak dicapai yaitu pertanian organik. Pada aspek orientasi ideologi, LPS juga mengalami pergeseran nilai-nilai non-komersialisme dan populisme yaitu menurunnya nilai-nilai tersebut. Perjalanan aksi LPS yang semakin besar cakupan kerja, area, dan spesifikasi teknis menyebabkan kebutuhan staf yang semakin besar, sehingga tidak semua staf yang direkrut mempunyai visi ideal LSM. Staf-staf ini memiliki hanya memiliki orientasi material (gaji) tidak lagi semangat yang visioner. LPS juga mulai masuk kedunia profit dengan menjual berbagai produk penelitian, baik kepada KSM maupun pasar. LPS juga menjadi distributor (membeli produk) dari petani organik untuk kemudian dijual ke pasar dengan jaringan yang dimiliki oleh LPS. Transaksi-transaksi yang dilakukan oleh LPS dengan KSM menunjukkan nilai-nilai populisme yang meluntur.

Penelitian ini mengungkapkan terjadinya pergeseran ideologi LSM baik LKTS maupun LPS (lihat kembali Sub Bab 7.3). Pada aspek ini, faktor internal dalam merespon perubahan yang terjadi (baik pada aspek finansial dan aksi) menjadikan LSM berubah orientasi ideologinya. Pihak donor tidak secara langsung mengintervensi perubahan orientasi ideologi LSM, LSM-lah yang memutuskan pada posisi mana berdiri. 


\section{Implikasi Studi}

Penelitian ini selain menjawab perumusan masalah penelitian, juga menghasilkan poposisi tipologi LSM. Pembahasan pada aspek finansial dan aksi mengidentifikasi adanya 2 tipe LSM yaitu LSM yang independen pada aspek finansial yang biasanya juga independen dalam aspek aksi, dan LSM yang idak independen, dalam proposisi ini dibedakan menjadi LSM dengan independensi finansial rendah dan tinggi. Pada aspek ideologi, LSM terdiri dari 2 tipe yaitu LSM yang tidak mengalami perubahan orientasi ideologi dan LSM yang mengalami perubahan orientasi ideologi. Dua tipe ini apabila disilangkan kan membentuk 4 kuadran/tipologi LSM.

Matriks Independensi LSM LKTS dan LSM LPS

\begin{tabular}{|l|l|l|}
\hline \multicolumn{1}{|c|}{ Independensi } & \multicolumn{1}{|c|}{ Finansial Rendah } & \multicolumn{1}{c|}{ Finansial Tinggi } \\
\hline $\begin{array}{l}\text { Aksi Dependen } \\
\text { (inisiasi, pelaksanaan } \\
\text { dan monitoring } \\
\text { program) }\end{array}$ & $\begin{array}{l}\text { Tipe I } \\
\text { Memiliki ciri-ciri sumber-sumber } \\
\text { dana tergantung kepada donor dan } \\
\text { kegiatannya terikat dengan } \\
\text { kepentingan donor } \\
\text { Dalam penelitian ini LKTS lebih } \\
\text { mendekati tipe ini }\end{array}$ & $\begin{array}{l}\text { Tipe II } \\
\text { Memiliki ciri-ciri } \\
\text { sumber-sumber dana } \\
\text { tidak tergantung kepada } \\
\text { donor dan kegiatannya } \\
\text { terikat dengan } \\
\text { kepentingan donor }\end{array}$ \\
\hline $\begin{array}{l}\text { Aksi Independen } \\
\text { (inisiasi, pelaksanaan } \\
\text { dan evaluasi program) }\end{array}$ & $\begin{array}{l}\text { Tipe III } \\
\text { Memiliki ciri-ciri sumber-sumber } \\
\text { dana tergantung pada sumber- } \\
\text { sumber dana tetapi memiliki } \\
\text { independensi terhadap pengelolaan } \\
\text { dana Dalam penelitian ini LPS } \\
\text { lebih mendekati tipe ini. }\end{array}$ & $\begin{array}{l}\text { Tipe IV } \\
\text { Memiliki ciri-ciri } \\
\text { sumber-sumber dana } \\
\text { tidak tergantung kepada } \\
\text { donor dan idependen } \\
\text { terhadap pengelolaan } \\
\text { dana }\end{array}$ \\
\hline
\end{tabular}

Sumber : Data primer diolah, 2008

Posisi dua LSM ini, berada pada kuadran yang berbeda, LKTS berada pada kuadaran independensi finansial rendah dengan ketergantungan dalam aspek aksi di lapang. Sementara LPS pada posisi independensi finansial rendah tetapi memiliki independensi dalam menginisiasi, melaksanakan dan mengevaluasi aksi di lapang. LKTS tidak mandiri dalam aspek finansial dan tergantung pada donor, sedangkan LPS walaupun secara finansial tidak mandiri, dana yang dihimpun secara bebas dapat dikelola dalam aksi LPS di lapang. Perbedaan ini disebabkan oleh karakteristik dana yang didapatkan. Dana yang dihimpun dari masyarakat tidak mempunyai kepentingan yang tinggi, sementara dana dari donor asing tidak lepas dari kepentingan-kepentingan.

Matriks ini tidak memberikan penjelasan mengenai pergeseran ideologi LSM. Perubahan orientasi ideologi LSM dalam penelitian ini tidak secara langsung sebagai akibat hubungan antara LSM dan donor. Tetapi lebih dari itu, dinamika perjalanan LSM baik secara internal dan eksternal telah memberikan corak yang lain pada orientasi ideologi yang diemban oleh lembaga ini. Kebutuhan yang perlu dipenuhi oleh LSM untuk bisa eksis dan menjadi lembaga yang represntatif bagi anggota dan masyarakat menjadi bagian penting dari proses bergesernya orientasi ideologi LSM. 


\section{KESIMPULAN}

Penelitian ini mengungkapkan bahwa kepentingan donor menyebabkan ketergantungan pada LKTS pada aspek finansial dan aksi, dalam hal ini LKTS dependen terhadap lembaga donor. Sementara untuk LSM LPS, kepentingan donor tidak memberikan pengaruh terhadap aksi LSM artinya LSM independen terhadap donor. LKTS selain tergantung secara finansial, lembaga ini juga tergantung dalam aksi baik dari aspek inisiasi, pelaksanaan maupun evaluasi. Sedangkan LPS walaupun sumber dana dari luar (dana masyarakat) tetapi pengelolaan dan evaluasi atas dana sepenuhnya menjadi wewenang LPS (Independen), LPS bebas melakukan inisiasi, melaksanakan, dan evaluasi atas program yang dibangun bersama KSM. Perbedaan independensi LSM pada aspek finansial dan aksi di atas muncul dari karakteristik donor, dimana LKTS menghimpun dana dari donor asing dengan agenda kepentingan yang lebih besar dan LPS menghimpun dana masyarakat secara partisipatif dengan kepercayaan pengelolaan kepada LPS.

Perubahan kepentingan donor menyebabkan perubahan fokus kegiatan LSM seperti yang dilakukan oleh LKTS. Perubahan kepentingan donor tidak terjadi pada LPS. LPS menolak masuknya donor diluar dana masyarakat dari ZISWAF, sehingga fokus kegiatan bisa lebih berkelanjutan. Faktor yang mempengaruhi pergeseran independensi LSM selain kepentingan donor adalah faktor kekuatan internal LSM. Faktor tersebut adalah: 1. Militansi ideologi LSM, 2.Kemapanan LSM dalam dana, 3. Kemapanan Kinerja LSM (Prestasi LSM) menjadi variabel kepentingan LSM dalam negosiasi atas kepentingan donor.

Penelitian ini juga mengungkapkan bahwa perubahan orientasi ideologi LSM tidak secara langsung sebagai akibat hubungan antara LSM dan donor. Pergeseran orientasi ideologi LSM lebih disebabkan oleh meningkatnya kebutuhan LSM dan pengalaman LSM untuk memiliki pendanaan mandiri. Kebutuhan LSM yang dimaksud adalah kebutuhan keuangan yang semakin besar karena meningkatnya aktifitas LSM. Kebutuhan tersebut perlu dipenuhi oleh LSM untuk bisa eksis dan menjadi lembaga yang represntatif bagi anggota dan masyarakat.

Dalam perspektif pendekatan pembangunan, LSM tidak serta merta menjadi organisasi gerakan sosial yang mampu mewujudkan mimpi kesuksesan pendekatan bottom up. LSM memiliki platform awal berdiri sebagai lembaga yang independen dari kepentingan luar dan membawa kepentingan sipil (civil sphere) mempunyai masalah ketergantungan pada donor di bidang finansial dan aksi dan LSM juga mengalami pergeseran orientasi ideologi.

\section{DAFTAR PUSTAKA}

Billah, M.M. dan Nusantara, Abdul Hakim G. 1988. Lembaga Swadaya Masyarakat di Indonesia Perkembangan dan Prospeknya. Prisma No 4, Tahun XVII. LP3ES: Jakarta

2000. Perkembangan Ornop di Indonesia. Proceeding Seminar Wawasan LSM di Indonesia. SMERU: Jakarta

Budiman, A. 1988. Menampung Aspirasi Masyarakat Lapisan Bawah. Prisma No 4, Tabun XVII. LP3ES: Jakarta 
BPS, 2008. http://www.bps.go.id/releases/files/kemiskinan-01jul08.pdf .

Cardoso, FH. 1982. Dependency and Development in Latin America in Introduction to The Sociology of Developing Countries. Monthly Review Express: New York

Christenson, J. A. and Jerry W. R.. 1989. Community Development in Perspective. Iowa State University Press: Iowa

Chapin, M. 2004. A Challenge To Environmentalists. World Watch November/December. Pp. 17-31

CPSM. 1993. Gerakan Transformasi Sosial Untuk Menegakkan Kedaulatan Rakyat di dalam Masyarakat Sipil yang Kokoh. Fajar Baru: Jakarta

Culla, A.S. 2006. Rekonstruksi Civil Society; Wacana dan Aksi Ornop di Indonesia. LP3ES: Jakarta .

Daldjoeni, N dan Suyitno, A. 1986. Pedesaan, Lingkungan dan Pembangunan. Penerbit Alumni: Bandung

Dharmawan, A.H. 2001. Farm Household Livelihood Strategies and SocioEconomics Changes in Rural Indonesia. Wissenchaftsverlag Vauk: Kiel

Dharmawan, A. H. 2002. Modul Pengembangan Komunitas Pedesaan Berkelanjutan. Program Magister Profesional Pengembangan Masyarakat. Sosek. Institut Pertanian Bogor: Bogor

Drabek, A. 1987. Development alternatives: The Challenge for NGOs.World Development. Vol 15. Pp 221-245

Eldridge, P. J.1989. LSM dan Negara. Prisma No.7. LP3ES: Jakarta

Eldridge, P. J. 1995. Non-Government Organisation and Democratic Participation in Indonesia. Oxford University Press: Oxford

Eyerman, R dan Jamison, A. 1995. Social Movement. Smelser (eds). Media, Culture \& Society. Pp. 449-468

Fakih, M. 2000. Masyarakat Sipil Untuk Transformasi Sosial: Pergolakan Ideologi LSM Indonesia. Pustaka Pelajar: Yogyakarta

Federke, J et al . 1999. Economic Growth and Social Capital: A critical Reflection. Kluwer Academic Publisher: Netherlands

Frank, A.G. 1973. The Development of Underdevelopment in C.K Wilber The Political Economy of Development. Random house: New York

Freire, P. 1984. Pendidikan, Pembebasan, dan Perubahan Sosial. Penerbit Sangkala Pulsar: Jakarta

Galtung, J. 1980. A Structural Theory of Imperialism in Dialectics of Third World Development. Montelair: New York.

Glen, A. 1993. Methods and Themes in Community Practice. In Butcher, $\mathrm{H}$ et al .(eds) Community And Public Policy: London 
Garcia, J. 1985. Can Participative Planning and management Be Institutionalized in Developing Countries? In Public Participation in Development Planing and Management Cases from Africa and Asia, by Jean Calude Garcia-Zamor (edited). Westivew Press: London.

Hannam, P. 1988. Pengembangan Bentuk Pembangunan Alternatif: Pengalaman LSM di Indonesia, Prisma, No. 4

Ismawan, B. 2002. Pemberdayaan Orang Miskin. Puspa Swara: Jakarta

Ibrahim, Rustam (2000). Direktori Organisasi Sumberdaya Masyarakat Sipil: Indonesia. The SynergosInstitute. Series on Foundation Building in Southeast Asia.

Ife, J. 1995. Community Development, Creating Community Alternatives-vision, Analysis and Practice. Longman House: Melbourne

Jenkins, J. C. 1983. Resource Mobilization Theory and The Study of Social Movements. Annual Review of Sociology. Vol. 9, pp 193-234

Johnson, D. PI. 1981. Sociological Theory Classical Founders and Contemporary Perspectives. John Wiley \& Son: New York

Korten, 1987. Third Generation NGO Strategies: A Key to People-Centered Developmen. World Development, Vol. 4. Pp 29-61

Lippit, R. 1985. Planed Change. Harcourt: Brace and World, Inc.

Martell, L. 1994. Social Movement and Social Change. C. University: New York

Nordholt. 1987. LSM dan Negara. Prisma. No. 3, Tahun XVI. LP3ES.Jakarta

Petras, J. Dan Veltemeyer, H. 2002. Imperialisme Abad 21. Kreasi Wacana: Yogyakarta

Rostow, W.W. 1964. The Stages of Economic Growth: A Non Communist Manifesto. Cambridge University Press: New York

Santos, D. 1970. The Structure of Dependence. American Economic Review, volume 3, pp 123-145

Stepan, A.C. 1978. The State and Society, Peru in Comparative Perspective. Pricenton University Press: New Jersey

Sajogyo. 1982. Modernization Without Development. The Journal of Social Studies: Bacca, Bangladesh

Shepherd, A.1998. Sustainable Rural Development. Macmillan. Basingstoke. London

Siregar, A. E. 1988. Pertumbuhan dan Pola Komunikasi LSM/LPSM. Prisma No 4, Tahun XVII. LP3ES: Jakarta

Sztompka, Piotr. 1993. Sosiologi Perubahan Sosial.Pernada Media: Jakarta

Sugiyanto. 2002. Lembaga Sosial. Global Pustaka Uta ma: Yogyakarta 
Sunarto, K. 2000. Pengantar Sosiologi. Lembaga Penerbit Fakultas Ekonomi Universitas Idonesia: Jakarta

Tribowo, D. 2006. Gerakan Sosial; Wahana Civil Society bagi Demokratisasi. Pustaka LP3ES: Jakarta

Ufford, PQ. dan Giri, AK. 2002. Kritik Moral Pembangunan. Kanisius: Jakarta.

Uhlin. 1997. Oposisi Berserak: Arus Deras Demokratisasi Gelombang Ketiga di Indonesia. Penerbit Mizan: Bandung

Uphoff. N. 1986. Local Institutional Development: An Annual Sourcebook, with Cases. Kumarian Press: West Hartford

Walhi. 2001. Mencoba Tegar di Tengah Badai Transisi, Laporan Tahunan Walhi. Dokumen Laporan: Jakarta

Walhi. t.thn. Manifesto WALHI: Metamorfosa Gerakan Lingkungan Hidup Indonesia: Jakarta 